\title{
ОРТОДОНТІЯ
}

UDC 616.28-008:616.31

V.D. Kuroiedova, Y.K. Sokologorska-Nykina, O.M. Makarova, Y.V. Rud

\section{THE STATE OF THE ORBICULARIS ORIS MUSCLE IN PATIENTS WITH HEARING DEPRIVATION}

\author{
Ukrainian Medical Stomatological Academy, Poltava, Ukraine \\ This research is a fragment of the initiative research work "Optimization of treatment and diagnostics of malocclusion in different age \\ periods" (number of state registration - 0118U004458).
}

Nowadays there are children with special needs; children with different significant deviations of hearing make up this category. In 2008, there were about 300 thousand children with hearing impairments in Ukraine. In 2013, the causes of childhood disability, the ear and mastoid diseases, occupied the 5th place in Ukraine [1].

An important pathogenetic factor in the formation of the dentofacial complex is the speech function. The low level of functioning of the muscular system of the maxillofacial area is not only a risk factor for the origin but also for the progression and relapse of dentofacial abnormalities and malocclusions [2]. The muscular function disorder of the maxillofacial area leads to morphological changes in the normal structure of the dental arch and the alveolar bone, which enhance already existing disocclusion [3].

During communication using sign language, deaf people do not use facial muscles at all or use them insignificantly. Deaf patients have found bigger electromyographic activity of the masticatory muscles [4] and bigger myographic activity of the orbicularis oris muscle during the rest in comparison with patients without hearing pathologies [5].

Investigation of the maxillofacial area muscles both in normal and with malocclusions represents a great interest, since the function of the muscles is an indicator of the complex functional relations of the dentofacial system [6].

The most modern, significant, objective and informative method of functional diagnostics of the dentofacial system is electromyography (EMG) [7]. Electromyographic examination of maxillofacial muscles is an important additional tool in the practice of orthodontist because a careful assessment of muscle activity before and during treatment helps to choose the necessary therapy, minimize the number of relapses [8].

The assessment of the functional status of the orbicularis oris muscle in children is quite difficult task, and moreover - in children with special needs, which includes hearing impaired children (HIC). In addition, the complexity of the analysis is the variety of clinical forms of each type of malocclusions, which are caused by different etiological factors [9].

The purpose of the research: to determine the bioelectric activity (BA) of the orbicularis oris muscle in a state of the rest and during the functional test "maximum arbitrary lips compression" in the HIC during the period of permanent bite.

\section{Materials and methods}

We have led a superficial EMG of the orbicularis oris muscle in $19 \mathrm{HIC}$ with permanent bite that were gathered into 1st group. All examined people had malocclusion. The average age of the surveyed patients was $18 \pm 0,42$ years. For the control group we used data from studies of patients with a permanent physiological bite without hearing disorders, defined by M.I. Dmitrenko (2nd group) [11].

For the study of BA of the orbicularis oris muscle the electromyography complex «Neurosoft» (Russia) was used. Research was carried out in standard conditions. The EMG of the orbicularis oris muscle was recorded for 5 to 10 seconds first in a state of physiological rest with closed lips - the first test, and then during performing a functional test - "maximum arbitrary lips compression" - the second test.

For the quantitative characterization of the interference curve, indicators such as maximum and average amplitude were used during the both tests. The digital material processing was made by a computer program. The probability of differences in the results obtained for different groups was determined using the Student's reliability t-test. Differences were considered probable in the commonly accepted in medicalbiological studies probability of error $p<0,05$.

\section{Results}

By analyzing the electromyographic status of the orbicularis oris muscle in $\mathrm{HIC}$ in a state of the rest, we have identified several trends (table 1). 
Average amplitude parameters of the orbicularis oris muscle biopotential (BP) oscillation (mcV) in the study groups in the rest (first test)

\begin{tabular}{|c|c|c|c|}
\hline \multirow{2}{*}{\multicolumn{2}{|c|}{ The orbicularis oris muscle }} & \multicolumn{2}{|c|}{ Study groups } \\
\hline & & 1st group & 2nd group \\
\hline \multicolumn{2}{|c|}{ Average value } & $126,5 \pm 13,06$ & $20,7 \pm 6,9$ \\
\hline \multirow{3}{*}{ Upper lip } & right & $118,5 \pm 8,44^{*}$ & $19,54 \pm 6,51^{*}$ \\
\hline & left & $136,5 \pm 13,17^{*}$ & $15,14 \pm 3,61^{*}$ \\
\hline & average value & $127,5 \pm 10,81^{*}$ & $17,34 \pm 3,44^{*}$ \\
\hline \multirow{3}{*}{ Lower lip } & right & $125,5 \pm 14,58^{*}$ & $25,16 \pm 12,13^{*}$ \\
\hline & left & $125,5 \pm 16,03^{*}$ & $22,96 \pm 11,18^{*}$ \\
\hline & average value & $125,5 \pm 15,31^{*}$ & $24,06 \pm 10,35^{*}$ \\
\hline
\end{tabular}

An analysis of the average parameters of the biopotentials of the orbicularis oris muscle in the HIC (1st group) revealed a disorder of the physiological balance. The average values of oscillations of the BP of the orbicularis oris muscle in the 1st group $(126,5 \pm 13,06 \mathrm{mcV})$ are in 6,11 times more (table 1) than in patients of the 2nd group $(20,7 \pm$ $6,9 \mathrm{mcV}$ ). This indicates a constant increase of the pressure of the orbicularis oris muscle in the HIC and the insufficient function of its relaxation.

In patients with hearing deprivation (1st group), biopotentials of the orbicularis oris muscle of the upper lip(127,5 $\pm 10,81 \mathrm{mcV})$ and the lower lip are almost the same $(125,5 \pm 15,31 \mathrm{mcV})$, in adults with orthognathic bite and sterling hearing the difference between the electromyographic parameters of the upper and lower lip is not statistically significant too.

Compared with the physiological norm, in the children of the 1st group in state of the rest the bioelectric activity of the orbicularis oris muscle of the upper lip $(127,5 \pm 10,81 \mathrm{mcV})$ is in 7,35 times higher than in the control group $(17,34 \pm 3,44 \mathrm{mcV})$. $\mathrm{BP}$ of the orbicularis oris muscle of the lower lip is also in 5,2 times higher than in the control group $(125,5 \pm 15,31 \mathrm{mcV}$ versus $24,06 \pm 10,35 \mathrm{mcV})$.
The evaluation of functional symmetry showed that BP of the orbicularis oris muscle of the lower lip in state of the rest in the HIC (1st group) is the same by indicators of right and left sides $(125,5$ $\mathrm{mcV}$ ), but there is an asymmetry in the work of the orbicularis oris muscle of the upper lip: $118,5 \pm 8,44$ $\mathrm{mcV}$ from the right and $136,5 \pm 13,17 \mathrm{mcV}$ from the left.

In the control group physiological symmetry is determined both in the work of both halves of the upper lip $(19,54 \pm 6,51$ and $15,14 \pm 3,61)$ and lower lip $(22,96 \pm 11,18$ and $22,96 \pm 11,18)$.

During performing the functional test "maximum arbitrary lips compression", the assessment of the average values of the biopotentials of the of the orbicularis oris muscle of the upper and lower lip in the 1st and 2nd groups patients showed that the indicators of the muscle biopotential oscillation amplitude in children with physiological bite (2nd group) $(290,55 \pm 56,06 \mathrm{mcV}$ ) exceed in 1,76 times the HIC indicators (group I) $(165 \pm 26,48 \mathrm{mcV}$ ) (table 2$)$, which is statistically confirmed $(p<0,05)$. So the work of the orbicularis oris muscle in the HIC during the compression is weakened in comparison with the norm almost in 2 times.

Table 2

Average amplitude parameters of the orbicularis oris muscle biopotential (BP) oscillation (mcV) in the study groups in the functional test "maximum arbitrary lips compression"

\begin{tabular}{|c|l|c|c|}
\hline \multicolumn{2}{|c|}{ The orbicularis oris muscle } & \multicolumn{2}{|c|}{ Study groups } \\
\cline { 3 - 4 } & Average value & 1 1st group & 2nd group \\
\hline \multirow{3}{*}{ Upper lip } & right & $165,0 \pm 26,48^{* *}$ & $290,55 \pm 56,06^{\star *}$ \\
\cline { 2 - 4 } & left & $192,5 \pm 15,99^{*}$ & $258,18 \pm 44,84$ \\
\cline { 2 - 4 } & average value & $136,5 \pm 13,17^{*}$ & $248,41 \pm 39,31$ \\
\hline \multirow{3}{*}{ Lower lip } & right & $164,5 \pm 14,58$ & $253,30 \pm 41,11$ \\
\cline { 2 - 4 } & left & $165,0 \pm 17,10$ & $312,41 \pm 71,83$ \\
\cline { 2 - 4 } & average value & $166,0 \pm 21,28$ & $343,19 \pm 71,96$ \\
\hline
\end{tabular}

In the patients with hearing impairments (1st group), the oscillation amplitude of the BP of the orbicularis oris muscle is almost the same (table 2) for the upper $(164,5 \pm 14,58 \mathrm{mcV})$ and lower lip (165,5 \pm $38,38 \mathrm{mcV}$ ), whereas in the norm (2nd group), that is in patients with physiological bite and hearing, the excitation of the orbicularis oris muscle of the lower lip $(327,80 \pm 71,00 \mathrm{mcV})$ is in 1,29 times higher than the upper lip $(253,30 \pm 41,11 \mathrm{mcV})$.
Comparison of the potential of the upper lip in the HIC (1st group) with the physiological norm (2nd group) showed the following: amplitude EMGparameters of the upper lip muscle in physiological bite (2nd group) were 253,30 $\pm 41,11 \mathrm{mcV}$, and in the HIC (1st group) is $164,5 \pm 14,58 \mathrm{mcV}$, so by $88,8 \mathrm{mcV}$ below, or in 1,5 times less muscle potential in children with hearing impairments and malocclusions; in EMG parameters of the lower lip mus- 
cle the regularity is repeated: in HIC with permanent bite the potential is reduced almost in 2 times.

In the analysis of the symmetry of the BP parameters of the orbicularis oris muscle, the maximum amplitude of the EMG-potential oscillations on the left and right sides of the upper and lower lip was estimated.

The work of the right and left orbicularis oris muscles of the upper lip in the HIC is characterized by insignificant asymmetry $(192,5 \pm 15,99 \mathrm{mcV}$ on the right and $136,5 \pm 13,17 \mathrm{mcV}$ on the left) $(p<0,05)$.

Indicators of activity of the BP of the orbicularis oris muscle of the upper lip on the right side in the 1st group are in 0,65 times lower compared to the same in patients of the 2 nd group $(p<0,05)$ : the indicator on the right side is lower in 0,75 times, on the left side - in 0,55 times. At the same time, the activity of the BP of the lower lip in the 1st group compared with the norm (2nd group) is almost in 2 times lower $(p<0,05)$ : on the left in 2,07 times $(p<0,05)$, on the right in 1,89 times.

Conclusions. Thus, the BP of the orbicularis oris muscle in the HIC with permanent bite has a significant deviation from the norm, namely, the hyperactivity of the muscle in 6,11 times in the state of the rest in comparison with the control group, which confirms data of Regalo, S., 2005. Functional peculiarities during the static test "maximum arbitrary lips compression" mean a disorder of the biodynamic balance of the near the mouth muscles in the HIC and decrease their activity almost in twice. For students with deprivation of hearing asymmetry in the work of both circular muscles of the upper lip and lower lip is characteristic.

The prospects for further research are seen in the improved studying of the maxillofacial area muscles activity in the HIC of different ages and with different malocclusions for forming the general characteristics of the myofunctional status of the maxillofacial area, which will allow to select preventive orthodontic measures and treatment of malocclusions differentially.

\section{References}

1. Шипко А.Ф. Современные аспекты сурдологической помощи детям Харьковского региона/ А.Ф.Шипко, Г.Р Муратов, А.С.Сенаторова// Актуальні проблеми сучасної медицини: Вісник української медичної стоматологічної академії.. 2014. - №2(46). Том 14 - С. 75 - 79.

2. Баринова Л. П. Характеристика формирования нёба у глухих и слышащих детей в период сменного прикуса/ Л.П. Баринова, Л.Д.Чучмай // Хирургическая стоматология: республиканский межведомственный сборник. Вып. 6 / редколлегия: Э.А. Александрова (отв. ред.), М.П. Барчуков, Ю.И. Бернадский и др; МЗУССР. - К. : Здоров'я. - 1973. - С. 61-63.

3. Otopalik, H. B. Early treatment symposium. American Journal of Orthodontics and Dentofacial Orthopedics. - 2002. - 122(6). - 15A.

4. Regalo, S. C., et al. "Electromyographic analysis of the masseter and temporal muscles in oralized deaf individuals." Electromyography and clinical neurophysiology. - 2005. - 46.4. - 217-222.

5. Regalo, Simone Cecílio Hallak, et al. "Electromyographic Analysis of the Orbicularis Oris Muscle in Oralized Deaf Individuals." Braz Dent J. 2005.- 16.3. - 237-242.

6. Лихота К.Н. Сравнительная характеристика зубочелюстной области пациентов с разными видами сагиттальных аномалий / К.Н. Лихота, А.В. Петриченко // Вестник стоматологии и челюстнолицевой хирургии. - Армения. - 2013. - № 3-4. C. 13-17.

7. Набиев Н.Б. Электромиография - современный метод диагностики функционального состояния мышц челюстно-лицевой области / Н.Б. Набиев, Т.В. Климова , Л.С. Персин ,Н.В. Панкратова //Ортодонтия.-2009. - №2.-С.13 -22.

8. Перегудов А. Б. Поверхностная электромиография как основа современной диагностики заболеваний окклюзионно-мышечно-суставного комплекса / А. Б. Перегудов, О. А. Малёнкина // Ортодонтия.- 2012. - №2. - 19-26.

9. Данилова М.А. Динамика показателей электромиографического исследования в процессе лечения миофункциональных нарушений у детей в периоде прикуса временных зубов / М.А.Данилова, Ю.В.Гвоздева, Ю.И.Убирия // Ортодонтия. - 2010. - №4 (52). - С.3-5.

10. Дмитренко М. І. Функціональна активність колового м'язу рота у пацієнтів із зубощелепними аномаліями, ускладненими скупченістю фронтальних зубів. Вісник стоматології. - 2012. - №3. 91-96.

Стаття надійшла 10.05.2019 p.

\section{Резюме}

3 метою вивчення функціонального стану у школярів із депривацією слуху та з зубощелепними аномаліями було проведено електроміографічне дослідження колового м'яза рота в 19 пацієнтів. Встановлено, що БП колового м'яза рота в ДВС у стані спокою має значне відхилення від норми, а саме, є наявна гіперактивність роботи колового м'яза. Амплітуда БП в стані функціональної проби «максимальне вольове стиснення губ» майже в два рази нижча за норму. Для школярів із депривацією слуху характерна асиметрія в роботі колового м'яза як верхньої губи, так і нижньої губи.

Ключові слова: зубощелепні аномалії, круговий м'яз рота, діти з вадами слуху.

\section{Резюме}

С целью изучения функционального состояния мышц у школьников с депривацией слуха и с зубочелюстными аномалиями было проведено электромиографическое исследование круговой мышцы рта у 19 пациентов. Установлено, что БП круговой мышцы рта в ДВС в состоянии покоя имеет значительное отклонение от нормы, а именно, является имеющаяся гиперактивность работы круговой 
мышцы. Амплитуда БП в состоянии функциональной пробы «максимальное волевое сжатия губ» почти в два раза ниже нормы. Для школьников с депривацией слуха характерна асимметрия в работе круговой мышцы, как верхней губы, так и нижней губы.

Ключевые слова: зубочелюстные аномалии, круговая мышца рта, дети с недостатками слуха.

UDC 616.28-008:616.31

\section{THE STATE OF THE ORBICULARIS ORIS MUSCLE IN PATIENTS WITH HEARING DEPRIVATION}

\section{V.D. Kuroiedova, Y.K. Sokologorska-Nykina, O.M. Makarova, Y.V. Rud}

Ukrainian Medical Stomatological Academy, Poltava, Ukraine

\section{Summary}

For the purpose of research of the functional state of students with hearing deprivation and malocclusion, an electromyographical study of the orbicularis oris muscle was performed in 19 patients. It is determined that the BP of the orbicularis oris muscle in the HIC in a state of the rest has a significant deviation from the norm, namely, there is a hyperactivity of the orbicularis oris muscle. The amplitude of BP during the functional test "maximum arbitrary lips compression" is almost twice lower than normal. For students with hearing deprivation, the asymmetry in the work of the orbicularis oris muscle, both the upper lip and the lower lip, is characteristic.

Key words: malocclusion, the orbicularis oris muscle, hearing impaired children. 